EDITORIAL

\title{
AN EDUCATIONAL RESPONSE TO STUDENT PROTESTS. LEARNING FROM HANNAH ARENDT
}

\section{Dirk Postma}

University of Johannesburg

Email: dpostma@uj.ac.za

\section{PROTESTS}

The higher education scene in South Africa has recently been dominated by student protests such as \#rhodesmustfall and \#feesmustfall. These movements express critique of social inequalities, colonial epistemologies, oppressive pedagogies, bureaucratic management in and financial exclusion from universities. They associate closely with workers' demands for insourcing (\#outsourcingmustfall) and decent remuneration.

The protests are part of the growing global awareness of the social and environmental unsustainability of neoliberal politics and global capitalist practices. They could be seen as part of what Raymond Williams (1965) calls the 'long revolution' towards self-governance. This continuing revolution could be detected among the South African 'born free' generation (those born after the establishment of the democratic state in 1994). This generation demands with new energy and urgency the continuation of the South African revolution through the realisation of the promises of democracy. As could be expected, the older generation, particularly those who were part of the democratic revolution in South Africa, are 'bewildered and angry when the new young generation asserts that the revolution has after all not

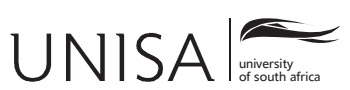

Education as Change Volume 20 | Number 1 | 2016 pp. 1-9
DOI: http://dx.doi.org/10.17159/1947-9417/2016/1042 Print ISSN 1682-3206 | Online 1947-9417 (c) 2016 The Author 
occurred' (Williams 1965, 12). Students are consequently confronted with forceful and violent resistance from the state and its apparatuses such as university managers with an emphasis on securitisation (Duncan 2014).

What is largely lacking in these reactions is an educational response that displays an awareness of the significance of these movements for the democratisation of society. Educators should be motivated by this demand for a better society to which education could contribute.

The question is therefore how we as educators and educational researchers should respond to the actions and voices of the students. This reflection aims to learn from Hannah Arendt who brings together a number of key issues, such as the significance of the new and the revolutionary spirit; violence, power and freedom; traditions and renewal; and democracy and the public sphere.

\section{BEGINNINGS}

In the active life, which is for Arendt (HC) constitutive of humanity, three kinds of activities could be distinguished: labour, work and action. Labour is the repetitive activity through which the conditions are created to sustain biological life. Through work the environment is transformed in the production of durable life contexts. Since both labour and work deal with the repetitive provision of the necessities of survival (food, shelter), they are instrumental towards determinable ends. While the activities of labour and work deal with instrumentality and predetermined ends, the activity of action is characterised by freedom.

To act is to begin something new. The newness of a beginning is possible because of natality, the fact that new humans are born into the world (R, 211; HC, 9). Each new human brings something uniquely new to the world. As an initiative, a beginning is also an act of freedom which does not simulate anything that came before. It is a miracle since it seems to appear from nowhere and could have unpredictable effects. These beginnings are essential to sustain the world, which is in constant need of renewal.

Beginnings as individual initiatives take place in the company of others where they are recognised and taken further. The proliferation of beginnings makes plurality characteristic of the human condition $(\mathrm{HC}, 8)$. Action is also boundless and unpredictable because it triggers a chain reaction among others that cannot be controlled or predetermined. It has the potential to 'force open all limitations and cut across boundaries' (HC, 199). Any attempt to determine the effects of actions or to shape the response of others deprives them of their own freedom to initiate a beginning. 


\section{REVOLUTION AND VIOLENCE}

Revolutionary beginnings are characterised by two different desires: a desire to be liberated from necessities and a desire to pursue positive freedom (R, 142). A beginning is a violation $(\mathrm{R}, 20)$ since the boundaries of the old cannot withstand the 'onslaught with which each new generation must insert itself' (HC, 191). The violations often turn violent when they appear in response to necessities. Violence is for Arendt $(\mathrm{HC}, 31)$ 'the prepolitical act of liberating oneself from the necessity of life for the freedom of the world'. She distinguishes rebellion, which aims at liberation from the necessities, from revolution, which aims at positive freedom (R, 142). Rebellions are meaningless if they do not lead towards the constitution of freedom. The 'spirit' of revolution is the drive to not simply transform the world but to change fundamentally the conditions of human life in order to realise freedom.

The contrast between liberation and freedom comes for Arendt to the fore in the difference between the American and French revolutions. The American Revolution aimed at the constitution of a society on the basis of freedom (R, 68, 92, 198). In contrast, the French Revolution was driven by liberation from the necessities of social needs in the pursuit of personal happiness. It is the dominance of social needs and necessities that caught the French Revolution in the cycle of destructive violence perpetuated by a revolutionary dictatorship. In contrast the drive for the life of freedom led to the constitution of a new political society in America. A revolution driven by social needs remains within a destructive cycle of violence because these drives cannot envisage a life of freedom after liberation. The true meaning of revolution for Arendt is therefore the 'foundation of freedom, that is, the foundation of a body politic which guarantees the space where freedom can appear' (R, 125). A revolution caught up in the cycle of violence constitutes the end of the political. Violence is anti-political since it is incapable of speech and speech is helpless when confronted with violence $(\mathrm{V}, 19)$.

\section{THE POLITICAL}

To be political means that everything is decided through words and persuasion and not through force and violence (HC, 26). The real purpose of revolution is the establishment of freedom through the constitution of a political public sphere (polis) of equal and free participation. The political is the space of action where beginnings could appear in the company of equals. It is only in the public sphere that is free from violence where positive freedom, plurality, action and excellence could thrive in the pursuit of public happiness $(\mathrm{R}, 130)$. It is where freedom and power come together. The political life demands courage from the individual to appear in the company of others and to strive towards excellence when judged by them. It is the life among equals where judgements are made about the best way to live among others and to constitute a better world. Arendt emphasises the importance of speech as political 
action. Action is the ability to find the right word at the right moment $(\mathrm{HC}, 26)$ in the presence of others.

While the political sphere could provide some boundaries to the boundlessness of action, it cannot predict or control where the beginnings would lead. The political sphere is not dependent on institutionalisation. The endurance of the political cannot be ensured through the prior creation of spaces or institutions. The polis itself is constituted through acting and speaking together $(\mathrm{HC}, 198)$. It is therefore important that the polis be kept alive through acting and speaking in order for beginnings to appear, freedom to be exercised and plurality to be pursued.

\section{THE EDUCATIONAL}

Education deals centrally with actions characterised by freedom and plurality. Participation in the public sphere is therefore a central element of education in a democracy. While education is located in the transition from the private sphere of the home to the public sphere, it participates in exactly the same actions that characterise the public.

For Arendt education introduces the new generation to the common world. The purpose is not to imprint the world that has to be accepted as such, but to show the world as a dynamic process in constant need of renewal. By introducing young ones into the common world they are made part of the world into which they are born. They are not introduced into an idealised world, but into a world with all its flaws and achievements. This educational introduction is, however, a paradoxical process since it is both the introduction of the world as it is and the creation of conditions under which the world could be renewed. This central task of education is presented by Arendt as follows:

Education is the point at which we decide whether we love the world enough to assume responsibility for it and by the same token save it from that ruin which, except for renewal, except for the coming of the new and young, would be inevitable. And education, too, is where we decide whether we love our children enough not to expel them from our world and leave them to their own devices, nor to strike from their hands their chance of undertaking something new, something unforeseen by us, but to prepare them in advance for the task of renewing a common world. (CE, 196)

Arendt emphasises here the responsibility of the educator whose task it is to introduce the new generation to the world in such a way that the world could be protected and renewed. Arendt furthermore separates education from politics when she criticises the pursuit of political programmes through education (CE). An education that serves political purposes does not promote freedom because it predetermines how the new ones are to renew the world. Biesta (2013), among others, criticises Arendt's separation of the educational and the political. While the presence of predetermined outcomes in education should be appreciated, for Biesta education deals centrally 
with human action and freedom, therefore with the political. The ontology of being born already provides the principle of the renewal of the world.

The student protests have also shown that any attempt to separate the educational from the political could not be more wrong. They have shown a keen sense of how education excludes the majority from participating in the public sphere of action and freedom. They have expressed the insight that education is the necessary means towards a full participation in the political. Education is therefore political in two senses: Extrinsically, it is affected by politics and enables political participation. Intrinsically, the political processes of enacting freedom are constitutive of education. Education is an inherent part of the political process of human interaction characterised by plurality and freedom.

Educational spaces are political spaces of a particular kind. They are spaces of reflection, of relative safety and reduced risks; courage is not assumed, but fostered; opportunities are provided to experiment with new beginnings and imaginations and to develop judgement; forgiveness could be cultivated and hope fostered. For Biesta, the introduction into the common world could only mean the enablement to participate in the public sphere by developing through participation the virtues and competences that characterise such a world.

\section{EDUCATIONAL RESPONSIBILITY}

The securitisation and eruption of violence on campuses are symptoms of failed political and educational processes. Politics fails when a significant part of the population is excluded from education and thereby from the common world. Education fails when the actions of students put the renewal of the common world at risk. When this happens we have, in the words of Arendt (CE), left students to their own devices by failing to make them part of the 'common world'. The inevitable effect is increased frustration and violence.

We encounter danger when student protests are not driven by the pursuit of freedom, but largely by social needs based on necessities related to educational exclusion and financial deprivation. The protests driven by necessities tend to remain within anti-political and anti-educational cycles of violence. The danger intensifies when universities are burdened with the task of dealing with these necessities and are distracted from engaging educationally with the students.

What follows is an attempt to be more specific about the responsibility of educators to engage with students.

\section{Fidelity to the event of the revolution}

The event of a revolution already points towards the inability of traditions to promote and sustain freedom $(\mathrm{R}, 162)$. The responsibility of the educator is to bring the revolutionary spirit into the public sphere so that the spirit could stay true to 
the pursuit and constitution of freedom. The spirit is kept alive when freedom is exercised through authentic interactions based on respectful deliberations. Such exercises and experiences of freedom are the only way in which to prevent violent reactions of frustration.

\section{Take responsibility for the world}

Educators have to take responsibility for the ways in which the revolutionary spirit has been suppressed prior to, but also after the constitution of democracy in South Africa in 1994. We have to take responsibility for the world as it is even though we may disagree with many of its features. This responsibility demands a response to students about the successes and failures in our struggles to keep freedom alive.

\section{Openness towards the new}

Educators have to confess their ignorance about the way in which the world will or should be renewed. The new beginnings are unbounded and unpredictable. Their most insightful attempts fall short in predicting or determining the world to come. Many educators who lived through the struggles that led to the constitution of a democracy in 1994 may have the impression that nothing new is at stake. Educators should pay attention to the ways in which 'old' values gain new meanings in changed contexts.

\section{Foster open spaces}

Educational spaces have to be opened up to the multiplicity of student voices. The failure to attend to student voices already excludes them from fuller participation in and care for the common world. This openness does not entail the endorsement of whatever is expressed or the cacophony of multiple voices, but an engagement about the ways in which the common world could be revolutionised through the refinement of deliberations and judgements in the pursuit of excellence in the public sphere.

\section{THIS ISSUE}

This is the first free open access issue of the journal in the spirit of the accessibility and openness of educational knowledge. The issue contains a variety of articles that critically investigate inequalities through which current configurations of power are maintained and entrenched. The positive tone present in the concrete proposals to change attitudes and practices displays hope about the ways in which education could be transformed.

The first two articles deal with different discourses in schools, one in relation to gender in a Scandinavian context and the other in relation to violence in the Western 
Cape. Brunila and Edström investigate the discourse of gender equality in preschools in Sweden and Finland. They introduce the concept of projectisation to refer to the market-orientated form of work, governmentality and subjectivity that filters through to schools. The discursive regime of projectisation contains a heteronormative bias that privileges masculinity by expecting girls to change in order to display masculine traits. Through their critique of projectisation, the authors 'trouble' the way masculine values are portrayed as the ideal in the preschool.

Davids and Waghid investigate the language of educators in a context of social problems such as violence, gangsterism, drug abuse, unemployment and crime in a school. They show how principals and teachers resort to disciplinary measures such as suspensions and corporal punishment that violate institutional policies and constitutional demands. They often respond in a derogatory 'language of violence'. One gains the impression of their frustration brought about by the lack of alternative strategies and support structures to deal with the violence in the community and the school. Davids and Waghid propose that this cycle could be broken by shifting from a language of violence to a language of becoming that emphasises social healing and engagement. This is a language of care, 'liking' and 'friendship' that enhances the humanity of all involved.

Two articles show how mentors benefit from their involvement with mentees. Archer and Parker show how young academics are developed through their own work as writing consultants in university writing centres. Their exposure to a variety of students and disciplines shapes their academic discourse and interdisciplinary insight.

O'Shea, McMahon, Priestly, Bodkin-Andrews and Harwood investigate a mentorship programme that aims at university access for indigenous young people in Australia. This is the first of two articles that deal with access of marginalised students to the university. They show how the pedagogy attempts to avoid a deficit approach by drawing on cultural resources of the mentees. The authors focus on the learning of the mentors enabled by the mutuality of the programme. They found that the mentors benefit from the programme by learning to appreciate indigenous culture. They also came to a better understanding of the history of Australia, learn ed how to respect indigenous knowledges and unlearned racism and stereotypes.

Norodien-Fataar investigates the pathways disadvantaged first-generation students create in order to gain access to the university. She extends Bourdieu's notion of cultural capital to analyse the nature and role of various kinds of capital within their communities. These students display 'sophisticated intellectual mediating capacity' by drawing on their 'community cultural wealth' such as the social capital in networks and emotional capital.

A similar emphasis on community resources is present in the next two articles on service learning. Preece uses the notion of adaptive leadership and asset-based development to query issues of power and equality between universities and 
communities. While adaptive leadership enables individuals and groups to accept responsibility for their decisions, an asset-based approach contributes towards the emancipation of communities from external mobilisers of change such as the university. It remains, however, a question of how community-based knowledge could inform legitimate university knowledge.

Bowie and Cassim report on a service-learning project where communication design students engage with prisoners in their own learning about a human-centred approach to design. The article reports on how students reflect on their interaction with prisoners. It testifies to the mutual benefit of an approach to design that takes the users' expressions of their needs seriously.

Koopman, le Grange and de Mink investigate phenomenologically the lived experiences and actions of a Physical Science teacher. This article provides a valuable contribution to the study of curriculum change by focusing on the meaning structures of a teacher. It portrays the teacher as someone who could often actively contribute towards his own learning against the odds of unsupportive colleagues and a deprived educational background.

Gebremedhin and Joshi critically compare the educational discourses in Mandela's statements with those within post-1994 policy statements. They detect a shift from an emphasis on human rights, empowerment and democracy, equality and social justice in Mandela's texts, towards a neoliberal emphasis on the economic functions of education in the policy documents. They show that this orientation towards the market perpetuates racial and class inequalities. They appeal for a return to the wisdom within the more balanced view of Mandela.

Cockcroft, Bloch and Moolla investigate the problem of psycho-educational assessment of school children's verbal learning abilities in a context of inequality. They express concern about the ways inequalities are reproduced when assessment is based on receptive and expressive vocabulary. They argue that working memory is less influenced by social and economic conditions and is therefore a more accurate indicator of learning abilities. They propose that tests based on working memory be included in order to obtain a more just assessment.

The introduction of the topic of evolution in the school curriculum brings a cognitive and moral dissonance related to the proper understanding of science and its methods. Against the background of poor teacher knowledge textbooks have become a central element in the acquisition of knowledge. Sanders and Makotsa investigate the quality and scientific soundness of textbooks by focusing on the way evolution is portrayed. They find numerous 'misconceptions' and 'unscientific ideas' about evolution as well as many ambiguous formulations. This raises questions about the writing, evaluation and selection of textbooks.

In light of the decline in the knowledge of science in South African schools, the interventions investigated by De Villiers, Plantan and Gaines are significant. They investigate an approach to the teaching of science in primary schools that is 
inquiry-based and experiential. They report on increased pupil involvement in and excitement about science activities related to this intervention. The participants also find that the pedagogies in South African schools are more varied and flexible in comparison with a focus in the United States of America on standardised tests.

\section{REFERENCES}

Arendt, H. 1961. The crisis in education. In Between past and future. Six exercises in political thought. Edited by H. Arendt, 173-196. New York: Viking Press. (CE)

Arendt, H. 1969. On violence. New York: Harcourt Brace Jovanovich. (V)

Arendt, H. 1990. On revolution. London: Penguin Books. (R)

Arendt, H. 1998. The human condition. $2^{\text {nd }}$ edition. Chicago: University of Chicago Press. (HC)

Biesta, G.J.J. 2013. The beautiful risk of education. London: Routledge.

Duncan, J. 2014. The rise of the securocrats. The case of South Africa. Johannesburg: Jacana Media.

Williams, R. 1965. The long revolution. Harmondsworth, UK: Pelican Books. 